\title{
Batik Tamarin Empowering Woman in Patimban Subang Indonesia
}

\author{
Arleti M. Apin, Belinda Sukapura Dewi, Ariesa Pandanwangi, Nuning Damayanti \\ DKV Institut Teknologi Harapan Bangsa, FSRD Universitas Kristen Maranatha, \\ FSRD Universitas Kristen Maranatha, FSRD Institut Teknologi Bandung \\ email: arletimapin@gmail.com, belinda.s.dewi@gmail.com , \\ ariesa.pandanwangi@maranatha.edu,nydamayanti10@gmail.com
}

Received: 04 March 2021; Revised: 26 April 2021; Accepted: 28 April 2021

DOI: http://dx.doi.org/10.37905/aksara.7.2.757-762.2021

\begin{abstract}
Patimban, a new port to help the inadequate sea passage of the Tanjung Periuk port in Jakarta. The location of this port is in the north of Java Island in Subang. With regard to the construction of this port, of course it will have an impact on the activities of the local community, who are dominant as fishpond fishermen. The Ministry of Transportation, through its dharma women, collaborates with a team of presenters open up economic opportunities for the local community. From several alternatives, the batik tamarin technique was chosen for fisherwives, this technique is relatively cheap and safe so it is very appropriate for them to learn. It is proven that in a short time they have been able to master this technique, big hopes for them to be able to develop it and economic opportunities will open up.
\end{abstract}

\section{Keywords}

Tamarind batik, woman empowerment, economy

\section{INTRODUCTION}

Patimban Port in Subang Regency, West Java, is a new port that will be inaugurated by the Government. The majority of the community's livelihoods are fishing in the sea. The coronavirus pandemic has slowed down economic activities and the movement of citizens (Azka, 2020). So, situation of the people economic activities in Patimban has stopped since the new port was built. Man do the fish farming and the woman help to process after harvesting. Seaside areas where they used to make pond to do fish farming is no longer exist, hence the only skill now they need to shift into another field to gain income. This need an immediate solution, the longer it is handled the worse social life it became. Action taken is simultaneously, giving shortcut skill to help them open a new way of life, from fisherman to became batik craftsmen. Batik tamarin is an alternative of batik making developed in a woman community in Bandung by the pioneer, Ibu Niken Apriani (Ayu, 2017) (Apriani \& Pandanwangi, 2020).Then this technique spread and taught in many different places in Indonesia, as well as abroad. Many impressive result and positive responses from everyone who have tried. This skill opens up new opportunities in batik making especially for new batik style, give new horizon and economic prospect in the future. Tamarind paste used to replace wax, is made from a mixture of tamarind seed powder, water and vegetable oil (Primayanti \& Lestari, 2019) (Mahardika et al., 2020). This is use in a cold or in a room 
temperature, applied onto the textile surface with help of an applicator; plastic piping bag or cake decoration tool (Pandanwangi et al., 2020) (Kartiwan, 2020). Paste can be made in a small quantity but also fine in larger amount but this will need airtight container to prevent getting moldy and store in refrigerator. Experiment prove refrigerated mixture over 3 months in good condition, ready to use. This is relatively ecofriendly way of creating batik, especially when using natural dyes.

\section{METHOD}

Mentoring method was used in this case, brief introduction of the technique for the start, with finished examples may gain their interest (Pandanwangi, 2020). Then they were to trace the pictures samples prepared onto the cloth. Then they learn how to make the tamarind paste and put inside a piping bag. In a spare cloth they try to control tamarind paste flowing until fine line produced. Next is trying to do in a stretched traced object fabric. After the paste is dry, next is coloring the object using fluid textile color dye. Other obstacle appear is the skill of drawing which is not possessed, each have their image but not able to actualized (Rianingrum, 2020). But then it is handled by combining image sample with another and modify to create a new image.

\section{RESULTS AND DISCUSSION}

Several days of training bring a promising new hope, it shows a remarkable result from the very first day until the closing programme. Astonishing finished products were made by this woman whom never do anything like it at all.

\section{RESULT}

Almost 50 female participants take part in these workshops, mostly they were housewifes, only 2 teachers, 2 governments staffs, 1 consumer good seller. Most of them can read and write but the local language is widely use and no interpreter to explain words from Indonesian to the locals.

Sketches are made in previous to stimulate and also give self convidence to start working. Tracing process with soft pencil $(5 \mathrm{~B}-6 \mathrm{~B})$ on textile, synthetic thin fiber is used this time to make shawl, so each get $100 \times 100 \mathrm{~cm}$ cloth stretch onto a wooden frame. This has to be done correctly so other step proceed smoothly. Working with this technique provide a horizontal space such a table or stands for the frame. Tamarind paste and later liquids dyes will run if the surface is not flat.
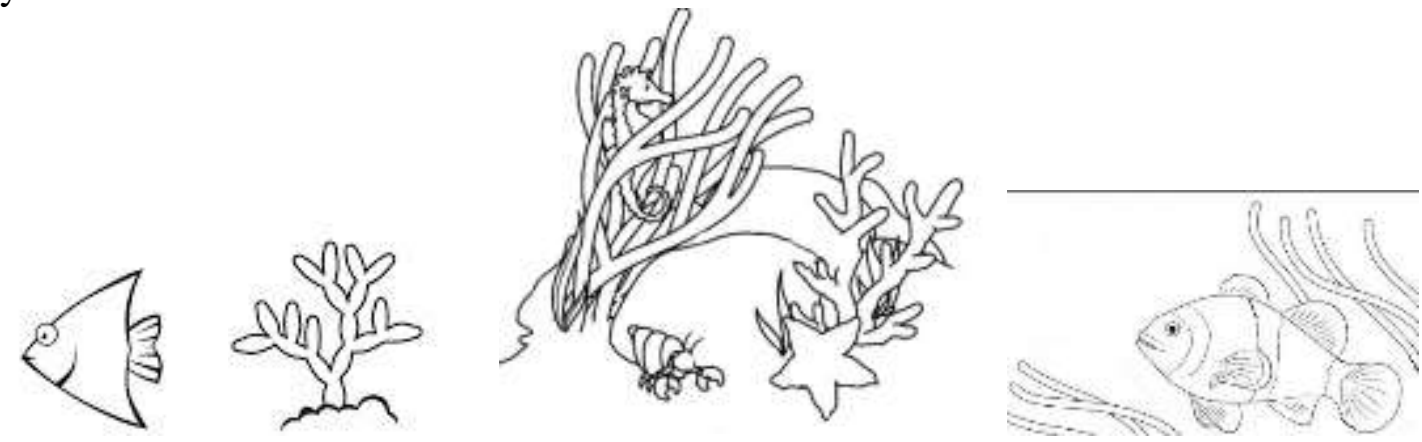

Figure 1. Sample of simple sketches

Source: Team Documentation 

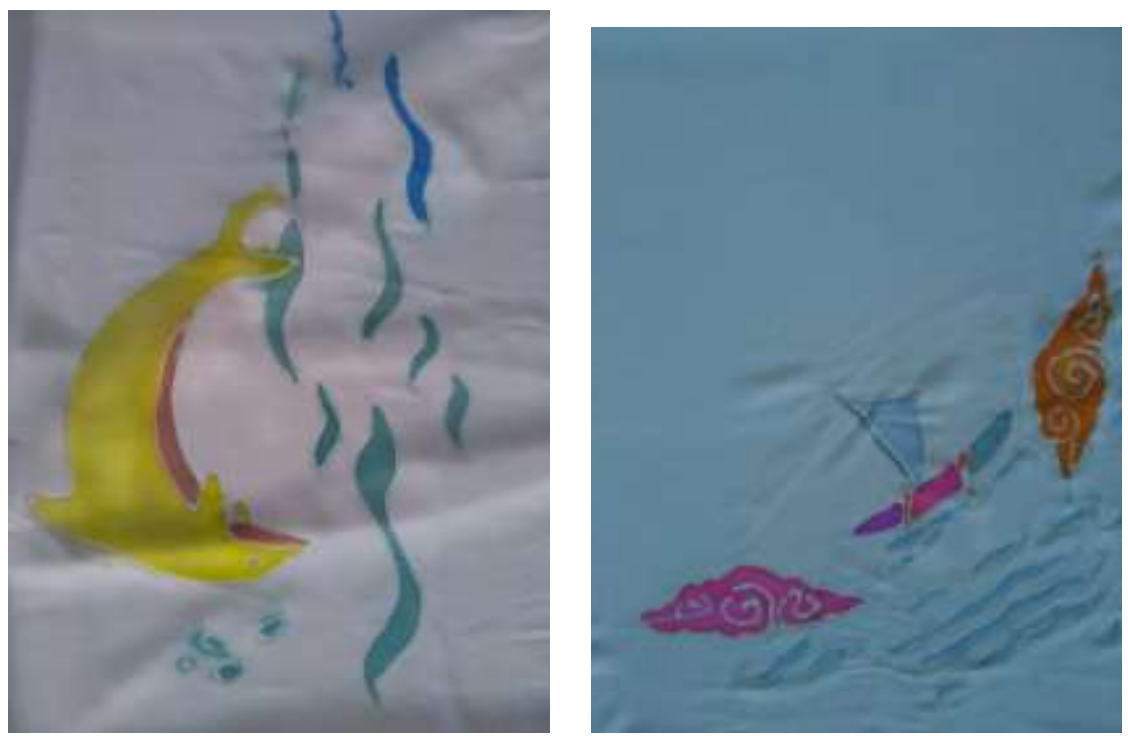

Figure 2. Samples of the first batik tamarin.

Source: Team Documentation

At the beginning, the workshop participants were introduced to batik, of course they thought they would get a difficult batik lesson and time-consuming, but this was on the contrary soon after they started practicing. Even though they were very nervous at first, but encouragement and curiosity emerge so that the first work could be completed, although not maximally. This can be seen from the composition made very simple, there is only a fish and ripples from the sea water under the jumping dolphin. The color used is very simple, namely only yellow on the back and brown on the stomach, while the color of water is only two, namely gray and blue. The line that is made looks very doubtful, it can be seen from the broken lines of the gutta tamarin, so that the thick line connection is visible due to the repetition.
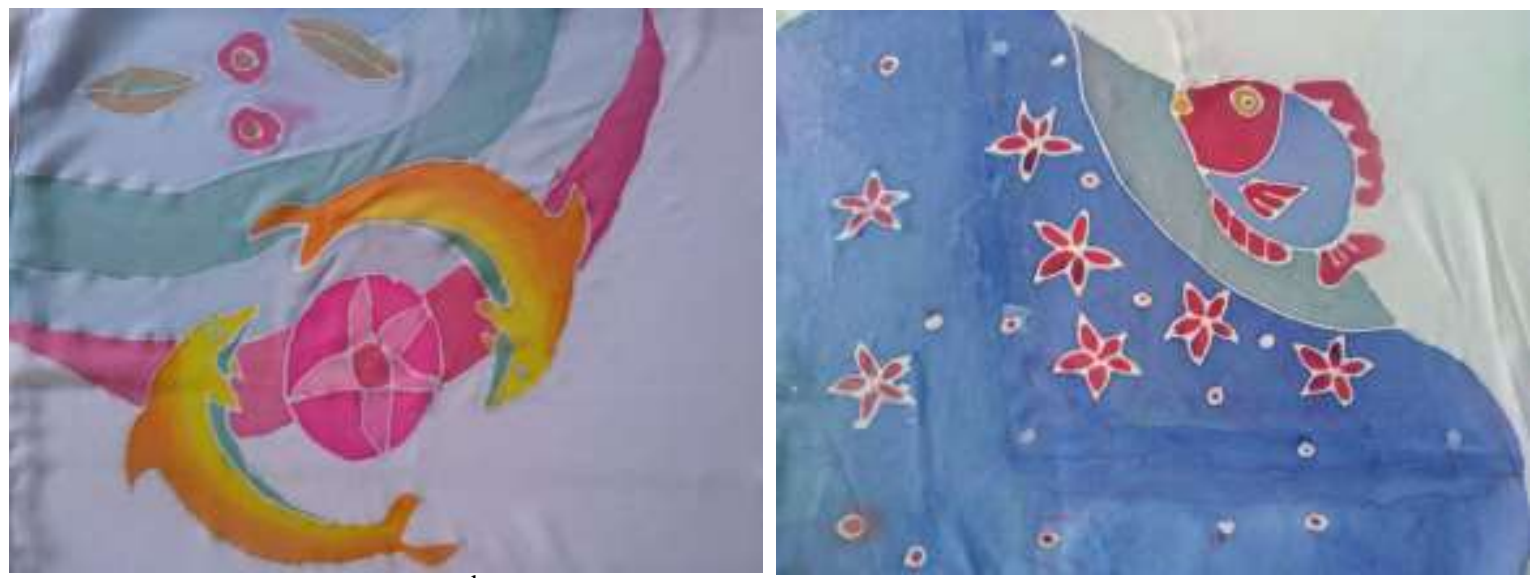

Figure 3. Samples of the $2^{\text {nd }}$ work exploring objects and coloring

Source: Team Documentation

In the second work more complex composition applied, there are 2 dolphins circling a round form in the middle. In the centre of the circle there is an object similar to a star. On 
the background 2 crescents behind dolphins. The curved shape is repeated under the pink crescent, with a different color, grayish green, under this gray curve there are 2 flowers and two leaves. The overall composition is very balanced, almost symmetrical, with two dolphins as a point of interest. The color of the dolphin is made using watercolor techniques, using a yellow to orange analogue color, the back is orange, the belly and head are yellow, on the belly there is a gray line that has a different thickness, the smaller the tail the line is and disappeared. The contrast colors of the lines and the fish as well as the thickness of the lines create a sense of motion. The line is also found on the other fish, so that both fishes seems to be chasing. The pink color which forms a monochromatic gradient on the crescent and star as the palest color and the dot color in the middle is the darkest color, making the composition one unit, with repeated curves.

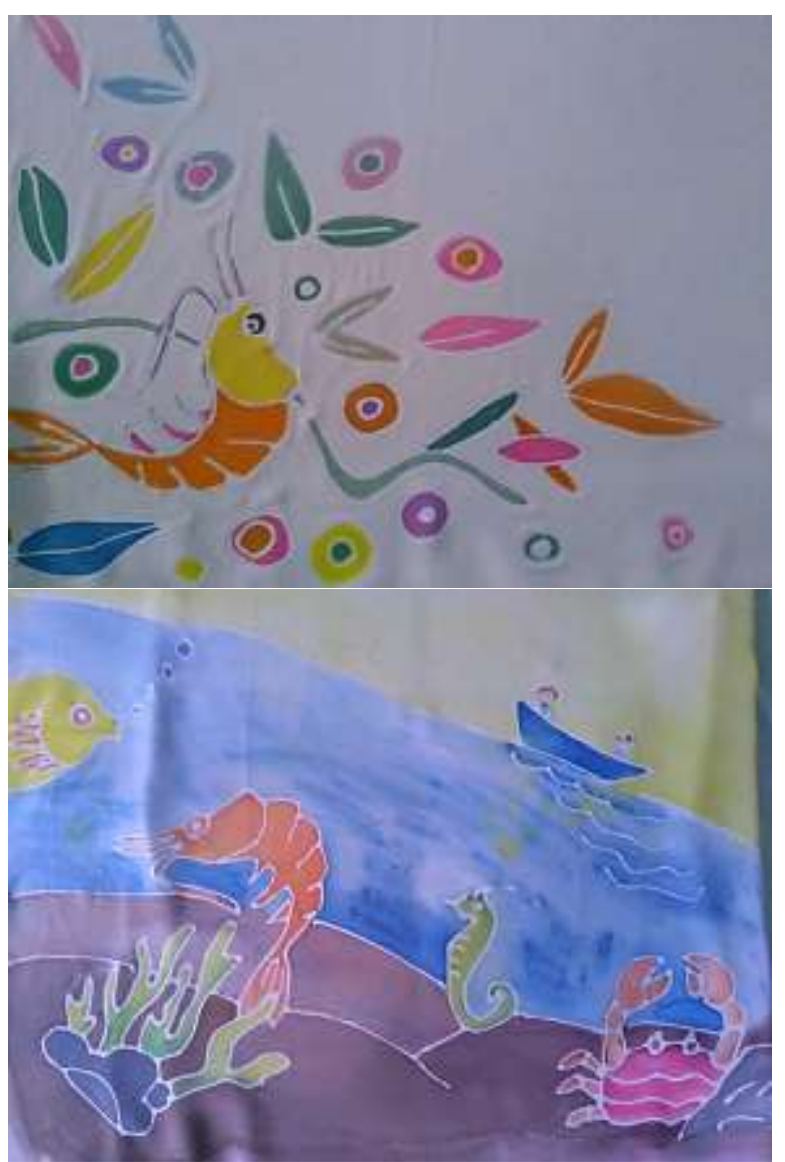

Figure 4. Samples of the $3^{\text {rd }}$ product combining images, enricheed coloring and neat lines Source: Team Documentation

The samples shown the $3^{\text {rd }}$ round of batik making, they performed such an improvement in the work. Stabile line quality emerges represent skills gained using tamarind paste, also using color exploring color shows how much enjoyment. Composition made of different object out of many sources combine to perform new object. On the left image they used shrimp from image provide, but cleverly mix with seaweed and add circles like bubbles. Choosing color were done freely without hesitation, they can represent feeling of joy instead of using logical color of the nature. Leaves form more to the plant around their 
environment in a colorful display. Where the right image composition tells about their perception of sea life. A boat on top of blue area applied in watercolor technique, and the bottom part in opaque brownish purple in a various shades. Four sea animals were shown; yellow fish, orange shrimp green, sea horse and a pink orange crab fish. Corals were colored in gradation of green to yellow on a blue - grey bottom. Coloring way on both works shows courage and flows of the feeling freely. The entire works perform similar spirits of happiness and joy in the making.

\section{DISCUSSION}

Turning the spirit of loving the work can be an advantage in the future, as they will do fine works then. Individuals approach were applied to meet the interest and also giving them logical explanation why should learn this bring a great passion and reason to accomplish all the lessons well. Empowering woman does not mean leaving their obligation, instead they can do sideline and even additional income for the family (Chant, 2016). Making batik tamarind while cooking or do laundry perhaps watching children is very possible tasks. Some of the product continue to the next step to a finished product ready to sell. Those are made into maskers, fans and many souvenirs.

\section{CONCLUSION}

Certainly, Batik Tamarind technique bring up many possibilities in empowering woman, relatively safe for children, environment, consider low cost to start a perfect solution for gaining additional income which may also be main income in the future. Continued supervision provides to ensure continuance advancement ecomical escalation.

\section{REFERENCES}

Apriani, N., \& Pandanwangi, A. (2020). Batik gutta tamarind.

Ayu, R. (2017). Kecintaan Terhadap Batik Buat Niken Kembangkan Perintang Warna dari Tepung Biji Asam. Tribunnews.Com. http://m.tribunnews.com/nasional/2017/08/08/kecintaan-terhadap-batik-buat-nikenkembangkan-perintang-warna-dari-tepung-biji-asam?page $=$ all

Azka, R. M. (2020). National Strategic Project: Jokowi's stake at Patimban Port. 14 Dec. https://www.pwc.com/id/en/media-centre/infrastructure-news/december2020/national-strategic-project-jokowis-stake-at-patimban-port.html

Chant, S. (2016). Women, girls and world poverty: Empowerment, equality or essentialism? In International Development Planning Review (Vol. 38, Issue 1, pp. 1-24). Liverpool University Press. https://doi.org/10.3828/idpr.2016.1

Kartiwan, I. (2020). Workshop Melukis Batik Gutta Tamarind pada Program Pengabdian kepada Masyarakat di Likupang, Manado, Sulawesi Utara. JabarBicara.Com. https://jabarbicara.com/workshop-melukis-batik-gutta-tamarind-pada-programpengabdian-kepada-masyarakat-di-likupang-manado-sulawesi-utara/

Mahardika, R., Fitra A, Y., \& Dewi K, E. (2020). Pelatihan Lukis Batik dengan Bubur Biji Asam Untuk Guru PAUD. IKRAITH-ABDIMAS Vol, 3(1), 1-7. https://journals.upi-yai.ac.id/index.php/IKRAITH-ABDIMAS/article/view/492/360

Pandanwangi, A. (2020). Transfer of Knowledge : Educational Value in Cold Wax Batik Technique Training Keywords: In A. Rahmat \& P. Chaube (Eds.), Variety of Learning Resolutions in the Covid 19 (pp. 51-55). Novateur Publication, India. 
https://novateurpublication.com/index.php/np/catalog/book/11

Pandanwangi, A., Apin, A. M., Sukapura Dewi, B., Damayanti, N., Denianshah, F., \& Elnissi., S. (2020). Adaptasi Pendampingan Teknik Membatik Media Alternatif Baru di Era New Normal. Peran Perguruan Tinggi Dalam Transformasi, Adaptasi, Dan Metamorfosisi Pengabdian Pada Masyarakat Di Era New Normal, 5(1), 2226.

Primayanti, N., \& Lestari, D. (2019). WORKSHOP BATIK GUTHA TAMARIN DALAM FESTIVAL SENI INTEGREAT FUKUOKA JEPANG

https://eprosiding.idbbali.ac.id/index.php/senada/article/view/124/95

Rianingrum, C. J. (2020). Pelatihan Melukis dengan Media Gutta Tamarind untuk Ibuibu di Kawasan bendungan Hilir-Jakarta. Universitas Trisakti. https://www.youtube.com/watch?v=Cj9y6z8u0uk 